\title{
Investigating Eggplant Fruit (Solanum spp.) Cultivated in Côte d'Ivoire for Their Physicochemical and Antioxidant Characteristics
}

\author{
Agnan Marie-Michel Combo ${ }^{1 *} \quad$ Patrick Aubin Dakia $^{2} \quad$ Obouo Hugues Jonathan Gildas Kobi ${ }^{1}$ \\ Djédoux Maxime Angaman ${ }^{1}$ \\ 1.Department of Biochemistry-Microbiology, Laboratory of Agrovalorization, Jean Lorougnon Guédé \\ University, BP 150 Daloa, Côte d'Ivoire \\ 2.Department of Food Science and Technology, Nangui Abrogoua University, 02 BP 801 Abidjan 02, Côte \\ d'Ivoire
}

\begin{abstract}
Eggplant is one of the most commonly consumed vegetables in Côte d'Ivoire. For this purpose, the nutrient constituents of eggplant varieties (Niguema, N'drowa, Aliona, Bello, Kotobi, Italy, Tiger, Kalenda and Gnangnan) were evaluated by standard procedures. The proximate composition in dry weight basis was significantly $(\mathrm{P}<0.05)$ varied and ranged: dry matter $86.72-93.29 \%$, crude protein $9.94-22.11 \%$, crude fat $5.07-20.43 \%$, crude fiber 23.15 $50.53 \%$, crude ash 5.14-10.09\%, carbohydrate $12.41-39.22 \%$, and energy value $211.53-320.94 \mathrm{kcal} / 100 \mathrm{~g}$. Gnangnan had the highest content in fat. Kalenda had the highest protein content, N'drowa had the highest fiber content, Bello had the highest content in carbohydrate, while Tiger presented the highest content in both ash and energy values. The phenolic content ranges from 618.28 to $977.35 \mathrm{mg} / 100 \mathrm{~g}$ while the vitamin $\mathrm{C}$ ranges from 92.88 to $150.59 \mathrm{mg} / 100 \mathrm{~g}$ in dry weight basis. Italy had the highest content in phenolic while Kalenda had the highest content in vitamin $\mathrm{C}$. Interrelationships between the parameters analysed and the different eggplant varieties were investigated by principal component analysis (PCA). PCA revealed differences between the eggplant varieties and classified them into three clusters on the basis of the measured parameters: Cluster 1 (Gnangnan), Cluster 2 (Niguema, N'drowa, Italy and Aliona) and Cluster 3 (Bello, Kalenda, Kotobi and Tiger) This study is a contribution to the knowledge of the nutritional composition of eggplant cultivated in Côte d'Ivoire. In view of these results, eggplant can help to reduce the nutrition-related disorders in Africa.
\end{abstract}

Keywords: Eggplant, Varieties, Proximate composition, Antioxidant

DOI: $10.7176 / \mathrm{FSQM} / 102-07$

Publication date: November $30^{\text {th }} 2020$

\section{Introduction}

Fruits and vegetables, being rich sources of nutrients, have been of interest due to their potential health benefits in preventing several chronic diseases (Slavin \& Lloyd 2012). Vegetables are considered essential for the diet of human in many parts of the world and play a significant role in human nutrition. They supply vitamins, minerals, dietary fiber and phytochemicals (João 2012).

Eggplant known as aubergine is a plant belonging to the Solanaceae family and to the genus Solanum (Chérifa 2014). The family Solanaceae is prevalent in tropical and subtropical regions of south America. Eggplant cultivation is possible in varied climates (temperate, tropical dry or humid). It contains different species and varieties which are distinguished in particular by the color, size and shape of the fruits (Furini \& Wunder 2004). It is of great economic importance because several species are cultivated and consumed in the world (Sultana et al. 2018). The most cultivated species are Solanum macrocarpon, Solanum melongena and Solanum aethiopicum (Wei et al. 2019). Unlike Solanum melongena, which is native to Asia (Meyer et al. 2012), S. macrocarpon and $S$. aethiopicum are native to Africa (Daunay et al. 2001).

Eggplants are nutritious and good source of vitamins and minerals (Mandal 2010). It is ranked among the top ten vegetables in terms of antioxidant capacity due to the phenolic constituents such as caffeic acid and chlorogenic acid (5-O-caffeoyl quinic acid) (Cao et al. 1996). They are used in traditional medicine and used to treat many diseases. Some authors reported that eggplant improves digestion, fights constipation, curing cancer, high blood pressure and hepatitis. It is also used to reduce cholesterol (Sangaré et al., 2009, Lekadou et al. 2019).

In sub-Saharan Africa, S. macrocarpon and S. aethiopicum are important because they are mostly used for their fruits and leaves (Schippers 2000). Eggplants are an essential component that enters in the diet. They are indispensable ingredients of soups or sauces that accompany carbohydrate staples (Chweya \& Eyzaguirre 1999).

In Côte d'Ivoie, since the 2000s, eggplant yields have increased significantly (Sangaré et al. 2009). Thus in 2017, the national production was estimated at 99000 tons with an average yield of 5.22 tons/ha (Lekadou et al. 2019). Different varieties of eggplant are cultivated and sold in Côte d'Ivoire for their economic and food potential and yet their nutritional contribution is unknown to consumers. Hence, an attempt was made in the present study to evaluate the nutritional and antioxidant characteristics of the different eggplant varieties consumed in Côte 
d'Ivoire in order to contribute to the knowledge on nutritional composition of these vegetables.

\section{Materials and Methods}

The biological material used in this study comes from the Laboratory of crop improvement, agroforestry Unit, Jean Lorougnon Guédé University (Daloa, Côte d'Ivoire). It consists of nine varieties of eggplant, including five varieties (Niguema, N'drowa, Kotobi, Aliona and Bello) of the specie S. aethiopicum, three varieties (Italy, Tiger and Kalenda) of the specie $S$. melongena and one variety (Gnangnan) of the specie $S$. anguivi (Figure 1). The three names (Niguema, N'drowa and Gnangnan) are from the Akan ethnic group in Côte d'Ivoire. The eggplant fruits were at physiological maturation and fresh. All reagents used in this study were of analytical grade.

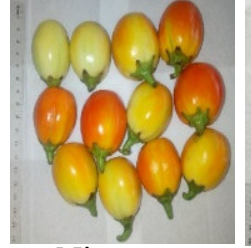

Niguema

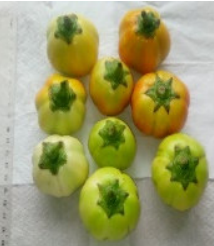

N'drowa

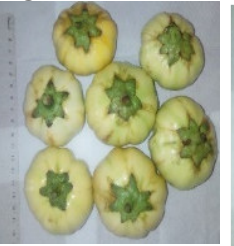

Kotobi

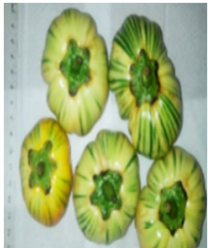

Aliona

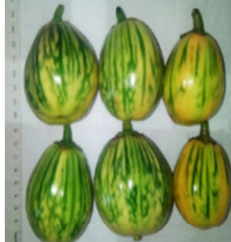

Bello

Solanum aethiopicum

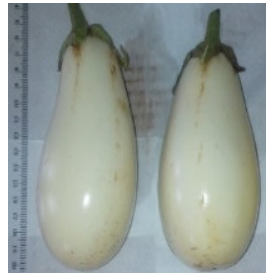

Italy

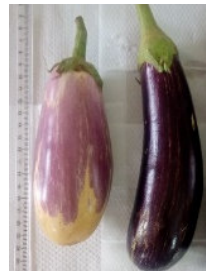

Tiger

Solanum melongena

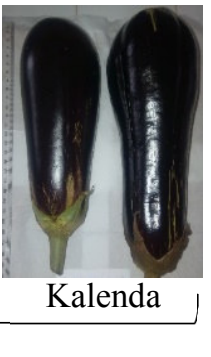

Kalenda

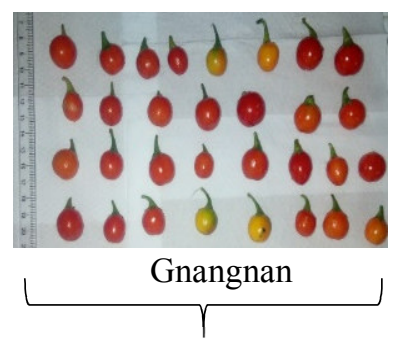

Solanum anguivi

Figure 1. Varieties of Eggplant Studied

\subsection{Preparation of Samples}

The eggplant fruits were transported to the laboratory. These fruits were washed with tap water and then with distilled water. The consumable parts were finely cut using a stainless steel knife into rings, oven-dried at $62^{\circ} \mathrm{C}$ for 24 hours, and grounded into fine powder and stored in an airtight container for experimental use. Determinations of physicochemical parameters and antioxidant content were carried out by triplicate. The results were expressed as gram per one hundred gram of dry matter (g/100 g DM).

\subsection{Determination of Physicochemical Parameters of Eggplant Species}

The samples were evaluated by the following analyses: $\mathrm{pH}$, dry matter, ash, crude protein, crude fat, crude fiber, total carbohydrate and gross energy. The methods of the Association of Official Analytical Chemists (AOAC 1995) were used for $\mathrm{pH}$ and dry matter determination. One hundred $\mathrm{mL}$ of distilled water was homogenized with $10 \mathrm{~g}$ of sample, and the $\mathrm{pH}$ was measured with a combined glass electrode $\mathrm{pH}-$ meter (Hanna Instruments, Romania). Dry matter was determined by hot oven (Memmert, Schwabach, Germany) drying at $105^{\circ} \mathrm{C}$ for 24 hours to constant weight.

The ash content was determined by incinerating $5 \mathrm{~g}$ of oven-dried eggplant samples in a muffle furnace at $550^{\circ} \mathrm{C}$ during $12 \mathrm{~h}$ (AOAC 1990$)$.

Crude protein was determined by using Kjeldahl method for the dosage of the total nitrogen (BIPEA 1976). About $1 \mathrm{~g}$ of eggplant was mineralized and heated with $25 \mathrm{~mL}$ of concentrated $\mathrm{H}_{2} \mathrm{SO}_{4}$ at $400^{\circ} \mathrm{C}$ for 2 hours, in the presence of potassium sulfate $\left(\mathrm{K}_{2} \mathrm{SO}_{4}\right)$ catalyst. The mineralisate sample was transferred into a $100 \mathrm{~mL}$ flask and adjusted with distilled water. Ten $\mathrm{mL}$ of the mineralized sample solution was taken and then $10 \mathrm{~mL}$ of $40 \% \mathrm{NaOH}$ was added and distilled for $10 \mathrm{~min}$. The distillate was trapped in a flask containing $20 \mathrm{~mL}$ of $2 \%$ boric acid and a mixed indicator (methylen bromocresol reagent). The content of the flask was titrated against $0.1 \mathrm{~N} \mathrm{HCl}$ until the solution became colorless. Crude protein was deduced by multiplying the percent total organic nitrogen $(\mathrm{N})$ by a conversion factor of 6.25 .

Crude fat was carried out by Soxhlet extraction with hexane as solvent (Razon et al. 2013). Ten grams of powdered eggplant were weighed into a cellulose cartridge. $300 \mathrm{~mL}$ of hexane was poured into previously dried and weighed round bottom flask. The sample was then placed into the soxhlet extractor and connected to a 
condenser. The crude fat was extracted for 4 hours at $68^{\circ} \mathrm{C}$.

Crude fiber was determined by digestion method (Wolf 1968). Two grams of sample was accurately weighed and transferred into beaker containing $50 \mathrm{~mL}$ of $\mathrm{H}_{2} \mathrm{SO}_{4}(0.25 \mathrm{~N})$. After boiling for 30 minutes under reflux refrigerant, $50 \mathrm{~mL}$ of $\mathrm{NaOH}(0.31 \mathrm{~N})$ was added and boiled. After 30 minutes, the solution was filtered. Residues were washed with hot water and transferred to crucible. Crucible containing residue was dried at $105^{\circ} \mathrm{C}$ for 8 hours to a constant weight. The crucible was then cooled in a desiccator and weighed. The residues were placed in muffle furnace at $550^{\circ} \mathrm{C}$ for 3 hours and then the sample was cooled in a desiccator and weighed. Crude fiber content was taken as difference between residues before and after incineration.

Total carbohydrate content was calculated adding the total values of crude protein, crude fat, crude fiber and total ash contents of the sample and subtracting it from 100\% according to Boakye et al. (2018).

The gross energy was calculated from the total carbohydrate content, crude protein and crude fat using the conversion factors for energy Atwater fruits namely 4 Kcal per $1 \mathrm{~g}$ of carbohydrate, 9 kcal per $1 \mathrm{~g}$ lipid and 4 kcal per $1 \mathrm{~g}$ of protein (FAO 2003).

\subsection{Determination of Antioxidant Content}

The total phenolic content in the eggplant was determined using the Folin-Ciocalteu reagent, gallic acid was used as standard (Singleton et al. 1999). Methanolic extracts of eggplant (1 mL) were transferred into different test tubes, and then mixed with $1 \mathrm{~mL}$ of Folin-Ciocalteu reagent. After $3 \mathrm{~min}$ for allowing the reaction to take place, $1 \mathrm{~mL}$ of $20 \%$ sodium carbonate $\left(\mathrm{Na}_{2} \mathrm{CO}_{3}\right)$ was added. The test tubes were placed in the dark for 30 min at ambient temperature, and the absorption was measured at $725 \mathrm{~nm}$ using spectrophotometer (DR 3900) against a blank, which contained methanol in place of sample. Gallic acid was used as calibration standard, and the total phenolic content was expressed as gallic acid equivalent in $\mathrm{mg} / 100 \mathrm{~g}$ dry weight (mg GAE/100g DW).

The ascorbic acid (vitamin C) content was determined according to the 2,6-dichlorophenol - indophenols dye method (Poncracz et al. 1971). Five grams of each sample was mixed with $40 \mathrm{~mL}$ of $2 \%$ metaphosphoric acid at room temperature. The mixture obtained was centrifuged at $3000 \mathrm{rpm}$ for $20 \mathrm{~min}$. The supernatant was introduced into a $50 \mathrm{~mL}$ flask and adjusted with distilled water. Test sample of the diluted sample was titrated with 2,6dichloroindophenol (2,6-DCPIP, $0.5 \mathrm{~g} / \mathrm{L})$ until it turns pale pink.

\subsection{Statistical Analysis}

The statistical processing of the data consisted of an analysis of variance (ANOVA) with a classification criterion using the Statistica software (Statistica 7.1). Means were compared by the Duncan test at the 5\% significance level. A principal component analysis (PCA) was also carried out using R software (version 3.5.0) in order to structure the variability between eggplant and nutritive content.

\section{Results and Discussion}

\subsection{Proximate Composition of Eggplant Varieties}

The proximate composition of eggplant varieties of the species S. aethiopicum, S. melongena and S. anguivi is shown in Table 1. There were significant differences $(\mathrm{P}<0.05)$ between eggplant varieties for the measured parameters (dry matter, $\mathrm{pH}$, ash, crude fat, crude protein, crude fiber, total carbohydrate and gross energy). The $\mathrm{pH}$ of the eggplant varieties ranged from 4.36 to 5.02. Gnangnan variety had the highest $\mathrm{pH}(5.02)$ while Italy variety had the lowest $\mathrm{pH}$ (4.36).

Regarding the dry matter, the values obtained from the nine eggplant varieties are between 86.72 and $93.29 \%$. Gnangnan variety recorded the highest content (93.29\%) while Tiger variety obtained the lowest content (86.72\%). These values obtained falls in line with the report of other previous researchers (Ossamulu et al. 2014). Indeed, these low water contents reflect the high solids content of the eggplant fruits. This facilitates their preservation.

The ash contents in the studied eggplant varieties varied from 5.14 to $10.09 \%$ on dry weight basis. The variety Tiger obtained the highest ash content $(10.09 \%)$ while the variety Gnangnan recorded the lowest ash content (5.14\%). Values obtained in this study were higher than those in the work of Agoreyo et al. (2012) which was within the range of $1.96-3.15 \%$.

The crude fiber contents of the eggplant varieties ranged from 23.15 to $50.53 \%$ on dry weight basis. The N'drowa variety with $50.53 \%$ was the most important source of fiber. The variety Tiger $(23.15 \%)$ recorded the lowest grade. These results are similar to those of Nwanna et al. (2019) which obtained high fiber value. The high value of fiber reported for eggplant fruit can improve its digestibility and absorption processes in large intestine, helping to stimulate peristalsis, thereby preventing constipation (Alaofe et al. 2008). This result established that the studied eggplant varieties can be ranked as fiber rich vegetable. The estimated value for crude fiber in Italy (37.27\%) and Kalenda (33.94\%) can be compared well with 39.19\% reported for S. melongena (Scorsatto et al. 2017).

With regard to fat, the results show that eggplant varieties contained a high fat content. These contents calculated on the dry weight basis varied between 5.07 and $20.43 \%$. Gnangnan variety had the highest fat content 
(20.43\%) while Aliona variety had the lowest content (5.07\%). The values of crude fat (5.07-20.43\%) in this study were lower than $37.66 \%$ DW for S aethiopicum (Eze \& Kanu 2014). The fat contents obtained for $S$ aethiopicum and $S$ anguivi species were respectively lower the $13.60 \%$ reported for $S$. aethiopicum and higher than the $15.20 \%$ reported for S. anguivi (Oyeyemi et al. 2015). The fat content in these eggplant varieties is low. They are therefore ideal fruits for people with incresead serum lipid levels, as solanum species have been reported to reduce low density lipoprotein (LDL)/high density lipoprotein (HDL) ratio and increase HDL/LDL ratio in hypercholesterolemic rabbits (Eletta et al. 2017).

Table 1. Proximate Composition of Eggplant Varieties (on Dry Matter Basis)

\begin{tabular}{lllllllll}
\hline Samples & $\mathrm{pH}$ & $\mathrm{DM}$ & Ash & C. fiber & C. fat & C. prot. & T. carb. & GE \\
\hline Niguema & $4.78^{\mathrm{d}}$ & $91.25^{\mathrm{d}}$ & $6.14^{\mathrm{b}}$ & $39.02^{\mathrm{d}}$ & $6.49^{\mathrm{ab}}$ & $20.07^{\mathrm{e}}$ & $28.29^{\mathrm{b}}$ & $251.85^{\mathrm{b}}$ \\
& \pm 0.02 & \pm 0.27 & \pm 0.02 & \pm 2.30 & \pm 0.17 & \pm 0.04 & \pm 2.50 & \pm 8.26 \\
N'drowa & $4.83^{\mathrm{e}}$ & $89.10^{\mathrm{b}}$ & $7.75^{\mathrm{cd}}$ & $50.53^{\mathrm{e}}$ & $8.39^{\mathrm{bc}}$ & $21.60^{\mathrm{g}}$ & $12.41^{\mathrm{a}}$ & $211.53^{\mathrm{a}}$ \\
& \pm 0.01 & \pm 0.30 & \pm 0.26 & \pm 0.94 & \pm 0.09 & \pm 0.09 & \pm 0.44 & \pm 0.62 \\
Aliona & $4.67^{\mathrm{c}}$ & $90.02^{\mathrm{bcd}}$ & $7.62^{\mathrm{c}}$ & $36.05^{\mathrm{cd}}$ & $5.07^{\mathrm{a}}$ & $9.94^{\mathrm{a}}$ & $31.56^{\mathrm{bcd}}$ & $211.57^{\mathrm{a}}$ \\
& \pm 0.00 & \pm 1.27 & \pm 0.12 & \pm 7.34 & \pm 0.52 & \pm 0.45 & \pm 6.30 & \pm 28.04 \\
Bello & $4.80^{\mathrm{de}}$ & $89.63^{\mathrm{bc}}$ & $7.65^{\mathrm{cd}}$ & $28.10^{\mathrm{ab}}$ & $5.55^{\mathrm{ab}}$ & $19.48^{\mathrm{d}}$ & $39.22^{\mathrm{e}}$ & $284.77^{\mathrm{cd}} \pm$ \\
& \pm 0.01 & \pm 0.18 & \pm 0.18 & \pm 1.12 & \pm 0.10 & \pm 0.09 & \pm 1.30 & 5.73 \\
Kotobi & $4.63^{\mathrm{b}}$ & $87.63^{\mathrm{a}}$ & $7.94^{\mathrm{cd}}$ & $29.38^{\mathrm{abc}}$ & $5.10^{\mathrm{a}}$ & $20.97^{\mathrm{f}}$ & $36.62^{\text {cde }}$ & $276.22^{\mathrm{bcd}}$ \\
& \pm 0.01 & \pm 0.16 & \pm 0.06 & \pm 2.77 & \pm 0.57 & \pm 0.00 & \pm 2.14 & \pm 13.70 \\
Italy & $4.36^{\mathrm{a}}$ & $90.44^{\mathrm{cd}}$ & $8.00^{\mathrm{d}}$ & $37.27^{\mathrm{d}}$ & $7.11^{\mathrm{ab}}$ & $11.50^{\mathrm{b}}$ & $36.13^{\mathrm{cde}}$ & $254.47^{\mathrm{bc}} \pm$ \\
& \pm 0.01 & \pm 0.06 & \pm 0.01 & \pm 1.87 & \pm 1.39 & \pm 0.01 & \pm 0.50 & 14.34 \\
Tiger & $4.63^{\mathrm{b}}$ & $86.72^{\mathrm{a}}$ & $10.09^{\mathrm{f}}$ & $23.15^{\mathrm{a}}$ & $10.78^{\mathrm{c}}$ & $18.80^{\mathrm{c}}$ & $37.20^{\mathrm{de}}$ & $320.94^{\mathrm{e}}$ \\
& \pm 0.01 & \pm 0.72 & \pm 0.23 & \pm 1.56 & \pm 2.17 & \pm 0.08 & \pm 0.50 & \pm 18.01 \\
Kalenda & $4.78^{\mathrm{d}}$ & $87.66^{\mathrm{a}}$ & $8.42^{\mathrm{e}}$ & $33.94^{\mathrm{bcd}}$ & $5.72^{\mathrm{ab}}$ & $22.11^{\mathrm{h}}$ & $29.83^{\mathrm{bc}}$ & $259.20^{\mathrm{bc}} \pm$ \\
& \pm 0.02 & \pm 0.28 & \pm 0.18 & \pm 1.32 & \pm 1.37 & \pm 0.28 & \pm 2.79 & 2.28 \\
Gnangnan & $5.02^{\mathrm{f}}$ & $93.29^{\mathrm{e}}$ & $5.14^{\mathrm{a}}$ & $46.02^{\mathrm{e}}$ & $20.43^{\mathrm{d}}$ & $10.11^{\mathrm{a}}$ & $18.32^{\mathrm{a}}$ & $297.55^{\mathrm{de}} \pm$ \\
& \pm 0.01 & \pm 0.09 & \pm 0.02 & \pm 1.68 & \pm 1.78 & \pm 0.12 & \pm 3.36 & 2.12 \\
\hline
\end{tabular}

Values are averages \pm standard deviation of replicate determinations $(n=3)$. Means not followed by the same superscript letters in the same column are significantly different $(\mathrm{P}<0.05)$. C. fiber $=\mathrm{Crude}$ fiber, $\mathrm{C}$. fat $=\mathrm{Crude}$ fat, C. prot $=$ Crude protein, $T$. carb. $=$ Total carbohydrate, $G E=$ Gross Energy.

The crude protein contents on the dry weight basis ranged from 9.94 in Aliona variety to $22.11 \%$ in Kalenda variety. The results in this study was higher than that reported by Uthumporn et al. (2016) in dried eggplant, which were in the range of $12-15 \%$. The protein content of Italy variety $(11.50 \%)$ is close to that of the variety Solanum melongena (13.34\% DW) mentioned by Scorsatto et al. (2017). Kalenda (22.10\%) and Tiger (18.80\%) have higher levels than this variety. The eggplant varieties may therefore be an ideal vegetable for protein supplementation. Indeed, Proteins play a very important role in the body. They are involved in the growth, development and maintenance of the body (Kouassi et al. 2013).

In terms of total carbohydrates, the contents obtained varied from $12.41 \%$ to $39.22 \%$ in N'drowa variety and Bello variety respectively. The studied eggplant varieties can be considered as sources of carbohydrates although they contain less than cereals. Italy (36.13\%) and Tiger (37.18\%) obtained similar levels but lower than those (57 - 65\% DW) of Rodriguez-Jimenez et al. (2018) on the variety Solanum melongena. The low carbohydrate observed in this study makes them good for diabetic patients and those watching their weight (Odetola et al. 2004).

The gross energy (GE) was calculated by multiplying the mean values of crude fat, crude protein and total carbohydrate by Atwater factors of 9, 4 and 4 respectively. The average gross energy values range from 211.53 $\mathrm{Kcal} / 100 \mathrm{~g}$ to $320.94 \mathrm{Kcal} / 100 \mathrm{~g}$. Tiger variety had higher energy value $(320.94 \mathrm{Kcal} / 100 \mathrm{~g})$ whereas N'drowa variety had the lowest content $(211.53 \mathrm{Kcal} / 100 \mathrm{~g})$ but this did not differ significantly from Aliona variety $(211.57$ $\mathrm{Kcal} / 100 \mathrm{~g})$. These GE are much higher than those of the four eggplant varieties $(22.90-34.02 \mathrm{kcal} / 100 \mathrm{~g} \mathrm{DW})$ analyzed by Ossamulu et al. (2014). This very strong VE observed indicates that the eggplant fruits of the present study can be a good source of energy for the body. 


\subsection{Antioxidant Contents of Eggplant Varieties}

Total phenolic and ascorbic acid contents in the nine studied eggplant varieties are presented in table 2.

Table 2. Antioxidant Contents of Eggplant Varieties

\begin{tabular}{lll}
\hline $\begin{array}{l}\text { Eggplant } \\
\text { Varieties }\end{array}$ & $\begin{array}{l}\text { Total phenolic } \\
(\mathrm{mg} \mathrm{GAE} / 100 \mathrm{~g} \mathrm{DM})\end{array}$ & Vitamin C (mg/100g DM) \\
\hline Niguema & $807.24^{\mathrm{bcd}} \pm 30.66$ & $105.21^{\mathrm{b}} \pm 0.31$ \\
N'drowa & $628.06^{\mathrm{ab}} \pm 49.38$ & $111.13^{\mathrm{bc}_{ \pm}} \pm 5.14$ \\
Aliona & $618.28^{\mathrm{a}} \pm 2.53$ & $123.29^{\mathrm{de}} \pm 2.96$ \\
Bello & $831.90^{\mathrm{cd}} \pm 58.80$ & $117.16^{\mathrm{cd}} \pm 4.96$ \\
Kotobi & $834.79^{\mathrm{cd}} \pm 186.58$ & $124.96^{\mathrm{e}} \pm 2.65$ \\
Italy & $977.35^{\mathrm{d}} \pm 19.47$ & $92.88^{\mathrm{a}} \pm 0.07$ \\
Tiger & $775.35^{\mathrm{ab}} \pm 70.34$ & $117.63^{\mathrm{cde}_{ \pm}} \pm 0.97$ \\
Kalenda & $967.58^{\mathrm{d}} \pm 28.87$ & $150.59^{\mathrm{f}} \pm 0.48$ \\
Gnangnan & $658.83^{\mathrm{abc}_{ \pm}} \pm 50.98$ & $118.98^{\mathrm{de}_{4}} \pm 4.43$ \\
\hline
\end{tabular}

Values are averages \pm standard deviation of replicate determinations $(n=3)$. Means not followed by the same superscript letters in the same column are significantly different $(\mathrm{P}<0.05)$. GAE: Gallic acid equivalent, DM: Dry Matter.

Total phenolic and ascorbic acid contents in the nine studied eggplant varieties are presented in table 2. Analysis of the antioxidant nutrients revealed differences between the eggplant varieties studied. In all cases, total phenolic was the major group of compounds. It varied between $618.28 \mathrm{mg}$ GAE/100g (Aliona variety) and 977.35 mg GAE/100g DW (Italy variety). The high values observed confirm that common eggplant is one of the vegetables with higher antioxidant capacity (Cao et al., 1996). However, the phenolic contents were lower than those reported (1540 mg/100 g DM) by Scorsatto et al. (2017) on the variety Solanum melongena. This difference in phenolic content could be due either to the variety of eggplant or to the stage of maturity of the eggplants. Thus, total phenolic content of eggplant is particulary important since works has shown a strong impact of phenolic compounds on reducing the risk of cancer and chronic diseases (Obrenovick et al. 2010).

Among the antioxidant nutrients, ascorbic acid or vitamin $\mathrm{C}$, a water soluble antioxidant play a vital role in protecting the body from infection and diseases. It is not synthesised by the human body and therefore must be acquired from fruits and vegetables. The vitamin C content ranged from 98.88 (Italy variety) to $150.59 \mathrm{mg} / 100 \mathrm{~g}$ DW (Kalenda variety) which were lower than those obtained (406 mg/100g DW and $197.77 \mathrm{mg} / 100 \mathrm{~g} \mathrm{DW})$ respectively by Eze \& Kanu (2014) and Arkoub-Djermoune et al. (2016). The reduction of the vitamin C content is mostly the result of thermal destruction and oxidation (Chuah et al., 2008).

\subsection{Differentiation Between the Eggplant Varieties Studied}

Principal component analysis (PCA) was used for revealing the relationships that might exist between different eggplant varieties by considering all parameters simultaneously. Thus, parameters such as dry matter, protein, fat, fiber, ash, carbohydrate, vitamin $\mathrm{C}$ and total phenolic were used as classification criteria. PCA has been done while considering the first two factors (F1 and F2) that explained $64.77 \%$ of the total information. The projection of the parameters studied is presented on the fig. 2 .
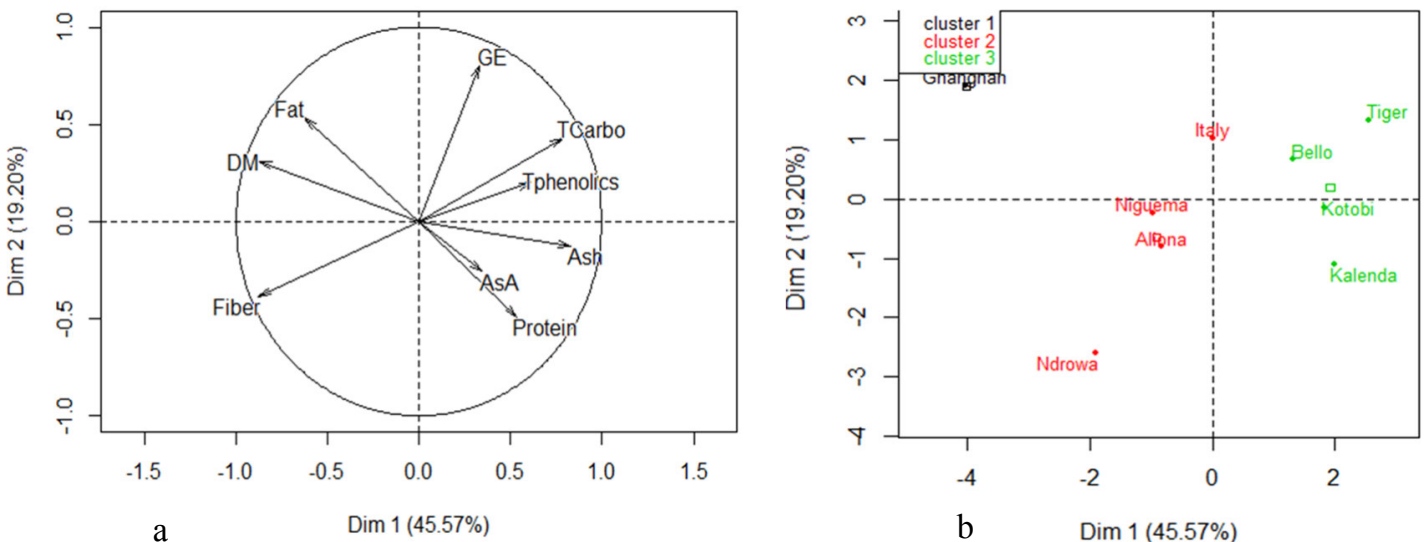

Figure 2. Principal Component Analysis: a) Correlation Circle (TCarbo = Total carbohydrate, AsA = Ascorbic acid, GE = Gross energy); b) Clustering of Eggplant Varieties on the Factorial Plane.

Observation of the correlation circle (Fig 2a) showed that the parameters studied are well represented, apart from ascorbic acid parameter. On the other land, most of the eggplant varieties were clustered around the center of the quadrant (Fig 2b). The point cloud of the eggplant varieties from the PCA revealed the presence of three 
groups according to their similarity criteria (Fig 2b). The first group includes the Gnangnan variety, characterized by its high fat content and low ash content. The second group includes the Niguema, N'drowa, Aliona and Italy varieties which mostly seem to have a high fiber content in common. The third group includes varieties sharing the parameters like protein, ash and carbohydrate. They are Tiger, Kalenda, Bello and Kotobi.

The result of the hierarchical cluster analysis (HCA) is shown as a dendrogram (Fig. 3) in which three well defined groups were visible. Group 1 contained Gnangnan alone, Group 2 was composed of Niguema, N'drowa, Aliona and Italy and group 3 comprised Tiger, Kotobi, Kalenda and Bello. Classification results of eggplant varieties are consistent between PCA and HCA. On one side, compared to PCA, HCA provides more detailed information regarding recognitions of subgroups. These groups are because of their differences good criteria for a better choice for the consumer.

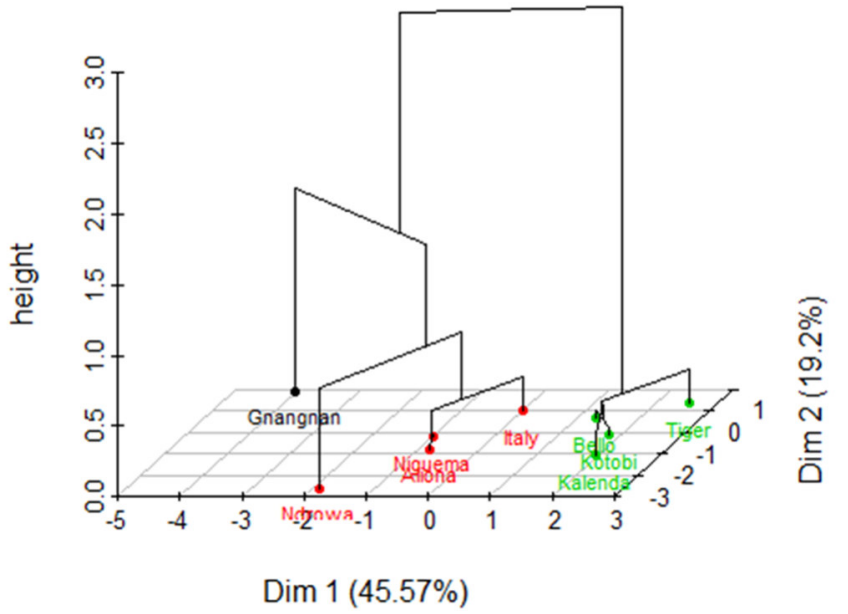

Figure 3. Dendrogram of Hierarchical Clusters of Eggplant Varieties.

\section{Conclusions}

The present work allows to know the nutritional composition of eggplant fruits cultivated in Côte d'Ivoire. The findings obtained shown that eggplants are good sources of essential nutrients, considering protein, fiber, ash. Therefore, promoting the consumption of such interesting vegetables will be beneficial to human health by providing the necessary macro-elements and energy to the body. The results obtained showed also that eggplants constitutes an important source of antioxidants that make them therapeutically beneficial.

\section{References}

Agoreyo, B. O., Obansa, E. S., \& Obanor, E. O. (2012), "Comparative nutritional and phytochemical analyses of two varieties of solanum melongena", Science World Journal, 7(1), 1597-6343.

AOAC, (1995), "Official methods of analysis", VA: Association of Official Analytical Chemists, Arlington, Washington D.C.

AOAC, (1990), "Official methods of analysis", (15th ed.). Association of Official Analytical Chemists, Arlington, Washington D.C.

Arkoub-djermoune, L., Boulekbache-makhlouf, L., Zeghichi-hamri, S., Bellili, S., Boukhalfa, F., \& Madani, K. (2016), "Influence of the thermal processing on the physicochemical propreties and the antioxidant activity of a solanaceae vegetable: eggplant", Journal of Food Quality, 39(3), 181-191.

BIPEA, (1976), "Bureau Interprofessionnel d'Etudes Analytiques", Recueil de méthodes d'analyses des communautés européennes, Gennevilliers, France.

Boakye, A. A., Wireko-Manu, F. D., Oduro, I., Ellis, W. O., Gudjónsdóttir, M., \& Chronakis, I. S. (2018), "Utilizing cocoyam (Xanthosoma sagittifolium) for food and nutrition security: a review", Food Science \& Nutrition, 6(4), 703-713.

Cao, G., Sofic, E., \& Prior, R. (1996), "Antioxidant capacity of tea and common vegetables", Journal of Agriculture and Food Chemistry, 44, 3426-3431.

Chérifa B, (2014), "Etude de l'activité antioxydante des polyphénols extraits de Solanum melongena par des techniques électrochimiques", Thesis, Mohamed Khider Biskra University, Algeria, May 2014.

Chuah, A. M., Lee, Y. C., Yamaguchi, T., Takamura, H., Yin, L. J., \& Matoba, T. (2008), "Effect of cooking on the antioxidant properties of coloured peppers", Food Chemistry, 111(1), 20-28.

Chweya, J. A. \& Eyzaguirre P. B. (1999), The Biodiversity of Traditional Leafy Vegetables. (Ed.) International Plant Genetic Resources Institute, Rome, Italy.

Daunay, M. C. Lester, R. N. \& Ano G. (2001), Eggplant. In A. Charrier, M. Jacquot, S. Hamon, \& D. Nicolas. 
(Ed.) Tropical Plant Breeding, CIRAD, Paris, France.

Eletta, O. A. A., Orimolade, B. O., Oluwaniyi, O. O., \& Dosumu, O. O. (2017), "Evaluation of proximate and antioxidant activities of ethiopian eggplant (Solanum aethiopicum L) and gboma eggplant (Solanum macrocarpon L)", Journal of Applied Sciences and Environmental Management, 21(5), 967-972.

Eze, S. O., \& Kanu, C. Q. (2014), "Phytochemical and nutritive composition analysis of solanum aethiopicum L.", Journal of Pharmaceutical and Scientific Innovation, 3(4), 358-362.

FAO, (2003), "Food energy - methods of analysis and conversion factors", Food and Agriculture Organization of United Nations, Rome.

Furini, A., \& Wunder, J. (2004), “Analysis of eggplant (Solanum melongena) related germplasm: morphological and AFLP data contribute to phylogenetic interpretations and germplasm utilization", Theoretical and applied genetics, 108(2), 197-208.

João, S. D. (2012), "Nutritional quality and health benefits of vegetables: A Review", Food and Nutrition Sciences, $3,1354-1374$.

Kouassi, J. B., Massara, C. C., Sess, D. E., Tiahou, G. G., Monde, A. A., \& Tia, E. V. (2013), “Determination of physico-chemical properties of two Varieties of okra traditionally dried", Journal of Food and Nutrition Sciences, 1(4), 38-42.

Lekadou, T. T., Coffi, P-M. J., Yao, S. D. M., \& Ama, T. J. (2019), "Vegetative growth response of eggplant (Solanum aethiopicum L.) to combined effects of fertilizer types and irrigation regimes applied on littoral tertiary soil in Côte d'Ivoire”, International Journal of Plant \& Soil Science, 30(5), 1-11.

Mandal, S. (2010), "Induction of phenolics, lignin and key defense enzymes in eggplant (Solanum melongena L.) roots in response to elicitors", African Journal of Biotechnology, 9(47), 8038-8047.

Meyer, R. S., Karol, K. G., Little, D. P., Nee, M. H., \& Litt, A. (2012), "Phylogeographic relationships among Asian eggplants and new perspectives on eggplant domestication", Molecular Phylogenetics and Evolution, 63, 685-701.

Nwanna, E. E., Ibukun, E. O., \& Oboh, G. (2019), "Nutritional content of selected species of tropical eggplant fruit (Solanum spp) diet Attenuates hepatic inflammation in high- fat fed male Wistar rats induced with streptozotocin", Food Science \& Nutrition, 7,109-119.

Odetola, A. A., Iranloye, Y. O., \& Akinloye, O. (2004), "Hypolipidaemic potentials of Solanum melongena and Solanum gilo on hypercholesterolemic rabbits", Pakistan Journal of Nutrition, 3(3), 180-187.

Obrenovich, M. E., Nair, N. G., Beyaz, A., Aliev, G., \& Reddy, V. P. (2010), "The role of polyphenolic antioxidants in health, disease, and aging", Rejuvenation Research, 13(6), 631-43.

Olaofe, O., Okiribiti, B. Y., \& Aremu, M. O. (2008), "Chemical evaluation of the nutritive value of smooth Luffa cylindrica seed's kernel”, Electronic Journal of Environmental, Agricultural and Food Chemistry, 7(10), 3444-3452.

Ossamulu, I. F., Akanya, H. O., Jigam, A. A., \& Egwim E. C. (2014), "Evaluation of nutriment and phytochemical constituents of four eggplant cultivars", Elixir Food Science, 73, 26424-26428.

Oyeyemi, S. D., Ayeni, M. J., Adebiyi, A. O., Ademiluyi, B. O., Tedela, P. O., \& Osuji, I. B. (2015), "Nutritional quality and phytochemical studies of Solanum anguivi (Lam.) fruits", Journal of Natural Sciences Research, 5(4), 99-105.

Pongracz, G., Weiser, H., \& Matzinger, D. (1971), “Tocopherols- antioxidant”, Fat Science Technology, 97, 90104.

Razon, L. F., Bacani, R. L., Evangelista, R. L., \& Knothe, G. (2013), "Fatty acid profile of kenaf seed oil”, Journal of the American Oil Chemists Society, 90(6), 835-840.

Rodriguez-Jimenez, J. R., Amaya-Guerra, C. A., Baez-Gonzalez, J. G., Aguilera-Gonzalez, C., Urias-Orona, V., \& Guillermo, N-M. G. (2018), "Physicochemical, functional, and nutraceutical properties of eggplant flours obtained by different drying methods", Molecules, 23(12), 1-13.

Sangaré, A., Koffi, E., Akamou, F., \& Fall, C. A. (2009), "État des ressources phylogénétiques pour l'alimentation et l'agriculture: Second rapport national", Ministère de l'agriculture, République de Côte d'Ivoire, 65 p.

Schippers, R.R. (2000), “African indigenous vegetables. An overview of the cultivated species”, Chatham, UK: Natural Resources Institute.

Scorsatto, M., Pimentel, A. C., Ribeiro da Silva, A. J., Sabally, K., Rosa, G., \& Moraes de Oliveira, G. M. (2017), "Assessment of bioactive compounds, physicochemical composition, and in vitro antioxidant activity of eggplant flour", International Journal of Cardiovascular Sciences, 30(3), 235-242.

Singleton, V. L., Orthofer, R., \& Lamuela-Raventos, R. M. (1999), "Analysis of total phenols and other oxidant substrates and antioxidands by means of Folin-ciocalteu reagent", Methods in enzymology, 299, 152-178.

Slavin, L., \& Lloyd, B. (2012), "Health benefits of fruits and vegetables", Advances in Nutrition, 3(4), 506-516.

Sultana, S., Islam, M. N., \& Hoque, M. E. (2018), "DNA fingerprinting and molecular diversity analysis for the improvement of brinjal (Solanum melongena L.) cultivars", Journal of Advanced Biotechnology Experimental Therapeutics, 1(1), 01-06. 
Uthumporn, U., Fazilah, A., Tajul, A., Maizura, M., \& Ruri A. (2016), "Physico-chemical and antioxidant properties of eggplant flour as a functional ingredient", Advance Journal of Food Science and Technology, 12, 235-243

Wei, Q., Du, L., Wang, W., Hu, T., Hu, H., Wang, J., David, K., \& Bao C. (2019), “Comparative transcriptome analysis in eggplant reveals selection trends during eggplant domestication", International Journal of Genomics, 2019(2), 1-12.

Wolf, J. P. (1968), “Manuel d'analyses des corps gras”, Azoulay; Paris, France. 